\title{
Gizarteratu eta Laneratzeko Euskal Eredua
}

\section{Ane Echebarria Rubio}

Gizarte Ekonomia eta Zuzenbide Kooperatiboko Institutua (Gezki), Euskal Herriko Unibertsitatea (UPV/EHU) ane.echebarria@ehu.eus

Enplegua desgaitasuna duten pertsonen gizarteratzerako tresna eraginkorra bihurtu da. Benetako gizarteratzeak berekin dakar desgaitasuna duten pertsonen eskubidea gainerakoen baldintza berdinetan lan egiteko, libreki aukeratutako lan baten bidez eta ingurune inklusibo eta ireki batean. Gizarteratu eta Laneratzeko Euskal Eredua osatzen duten erakundeak, berrogei urteko esperientzia dutenak, erreferente bilakatu dira Europa mailan. Helburu nagusia laguntza-behar handienak dituzten pertsonentzat kalitatezko enplegua sortzea eta lan-merkatu arruntera igarotzeko bidea erraztea eta ahalbidetzea izan dira. Bestalde, desgaitasuna duten pertsonen eskubideei buruzko Nazio Batuen Konbentzioak aurrerapen handia suposatu zuen kolektiboaren eskubideen tratamenduan, desgaitasuna giza eskubideen ikuspegitik heltzen duena. Aldaketa hau enpleguaren eremuan eman zen ere, eta Konbentzioak defendatzen duen eredua Euskadiko ereduarekin lotura handiak ditu. Arrazoi hauengatik, bereziki interesgarria bihurtu da Gizarteratze eta Laneratzeko Euskal Eredua Nazio Batuen Konbentzioaren ikuspegitik aztertzea.

\section{GAKO-HITZAK}

Desgaitasuna, enplegua, gizarteratzea, eredua, Euskal Autonomia Erkidegoa.
El empleo se ha convertido en una de las herramientas más eficaces para la inclusión social de las personas con discapacidad. La verdadera inclusión supone, entre otras cosas, el derecho a trabajar en igualdad de condiciones con las demás personas, en un trabajo libremente elegido y en un entorno abierto e inclusivo. Las entidades que conforman el Modelo Vasco de Inclusión Sociolaboral, con más de cuarenta años de experiencia, se han convertido en un referente a escala europea. Su objetivo principal es crear empleo de calidad para las personas con más necesidades de apoyo y facilitar el paso al mercado laboral ordinario. Por otro lado, la Convención de Naciones Unidas sobre los Derechos de las Personas con Discapacidad supuso un antes y un después en el modelo de tratamiento de los derechos del colectivo. También supuso un cambio en el ámbito del empleo, un modelo que se puede identificar con el de nuestro territorio. Es por estas razones por las que resulta interesante analizar el Modelo Vasco de Inclusión Sociolaboral a la luz de la Convención de la ONU.

\section{Palabras clave}

Discapacidad, empleo, inclusión, modelo, Comunidad Autónoma Vasca. 


\section{Sarrera}

Nazio Batuen Batzar Nagusiak 2006ko abenduaren 13an onartu zuen Desgaitasuna duten Pertsonen Eskubideei buruzko Konbentzioak, mugarri bat suposatu zuen kolektiboaren eskubideen tratamenduan. Konbentzioak gizarte inklusibo baten aldeko apustua suposatu zuen, desgaitasuna giza eskubideen ikuspegitik eta eredu sozialetik heltzen duena. Ituna funtsezko bi helbururekin jaio zen: lehena, bereizkeriaren aurkako eta inklusio osoaren aldeko borroka; eta bigarrena, desgaitasuna duten pertsonen eskubideen aitorpena.

Itunak planteatzen duen ereduaren arabera, benetako gizarteratze eraginkorrak berekin dakar, beste gauza batzuen artean, desgaitasuna duten pertsonen eskubidea gainerakoen baldintza berdinetan lan egiteko, libreki aukeratutako lan baten bidez eta ingurune inklusibo, ireki eta eskuragarri batean. Enplegua desgaitasuna duten pertsonak gizarteratzeko tresna eraginkorra da eta izan da, horregatik, politika aktiboen funtsezko helburuetako bat bilakatu da. Aurrerago ikusiko den bezala, kolektiboarentzako dauden enplegu mota desberdinek eta eremu honetan sortzen diren zailtasunak gainditzeko dauden neurriek, interes bereziko gaia bihurtzen dute.

Gizarteratu eta Laneratzeko Euskal Eredua Euskadiko gizarte-ekimen publikoko erakundeek kudeatzen dute, desgaitasuna duten pertsonen laneratzean oinarrizko tresna bilakatu direnak. Helburu nagusia laguntza-behar handienak dituzten pertsonentzat kalitatezko enplegua sortzea, eta aldi berean, lanmerkatu arruntera igarotzeko bidea erraztea eta ahalbidetzea izan dira. Euskal erakundeak, sektorean berrogei urte baino gehiagoko esperientzia dutenak, estatu eta mundu mailan erreferente bilakatu dira. Bestalde, erakunde mota hauek ekonomia sozial eta solidarioko sektorearen parte dira, legediak horrela aitortzeaz gain, ekonomia egiteko beste modu honen balio eta printzipio guztiak partekatzen dituzte.

Artikulu honen helburu nagusia desgaitasuna duten pertsonen laneratzea aztertzea da, betiere, esparru honetan ibilbide luzea duen Gizarteratu eta Laneratzeko Euskal Ereduaren ezaugarrietan oinarrituta. Bestalde, desgaitasuna duten eskubideei buruzko Nazio Batuen Konbentzioak sektore honi ekarri dion aurrerapenaren analisia egingo da, bi ereduen arteko elkarguneak ezagutu ahal izateko. Modu honetan, kolektiboaren enpleguari buruzko hausnarketa egingo da, elementu positiboak azpimarratzeaz gain, sektoreak pertsona guztientzat inklusiboa den gizarte bat lortzeko dituen erronkak nabarmenduko direlarik. Metodologiari dagokionez, ikerlan honetan legislazioa eta araudia aztertzeaz gain, hainbat adituren bibliografia-azterketa egin da. Bestalde, iturri ofizial eta ez ofizialetatik datozen hainbat datu estatistikoen analisia egin da.

Bukatzeko, lan honen oinarrian Gizarte Ekonomiako Euskal Behatokiak (OVES/GEEB) eta Euskal Herriko
Unibertsitateko Gizarte Ekonomia eta Zuzenbide Kooperatiboko Institutuak (Gezki) elkarlanean egin duten txostena dago (Bengoetxea, Etxebarria, Morandeira eta Soto, 2019). Bertan, Gizarteratu eta Laneratzeko Euskal Ereduaren azterketa sakona egiten da eta euskal eredua Desgaitasuna duten Pertsonen Eskubideei buruzko Nazioarteko Konbentzioaren ereduarekin lotzen dute.

\section{Desgaitasuna duten pertsonen enplegua}

Desgaitasuna duten pertsonen enplegua aztertu aurretik, egokia izango litzateke desgaitasunaren eta desgaitasuna duen pertsonaren kontzeptuak argitzea.

Azken urteotan, desgaitasunaren ikuspegiak bilakaera nabaria izan du, atzean utzi baitu pertsonen urritasunetan arreta jartzen zuen ikuspegi paternalista ${ }^{1}$ eta eredu sozialean zentratu da, kolektiboaren giza eskubideetan oinarritzen dena. Egun, Desgaitasuna duten Pertsonen Eskubideei eta Haien Gizarteratzeari buruzko Lege Orokorrak ${ }^{2}$ (aurrerantzean, LGDPCD, gaztelaniako siglez ezaguna dena) definitzen du desgaitasuna, eredu soziala babestuz eta aurreko arauen erreferente medikua gaindituz (De Fuentes, 2016). Legearen 2.a artikuluak dio:

Egoera bat da, urritasun aurrez ikusteko moduan iraunkorrak dituzten pertsonek oztopoak aurkitzen dituztenean sortzen dena, oztopo horiek mugatu edo eragotzi egiten dietelarik gizartean egiaz eta erabat parte hartu ahal izatea, gainerakoen baldintza berdinekin.

Ildo beretik doa Desgaitasuna duten Pertsonen Eskubideei buruzko Nazio Batuen Nazioarteko Konbentzioak (aurrerantzean, DPEK) bere 1. artikuluan ematen duen desgaitasuna duen pertsonaren definizioan:

Pertsona desgaituen artean badira epe luzaera gabezia fisiko, mental nahiz intelektualak edo zentzumenezko gabeziak izango dituztenak, eta oztopo desberdinekin topo egitean gabezia horiek eragotzi ahal izango dute pertsona horiek gizartean parte hartzea osotasunean eta eragingarritasunez, gainerakoen baldintza berberetan.

\footnotetext{
1 "Gaixotasunaren ikuspegitik aipatzen da desgaitasuna, eta desgaitasuna duten pertsonek gizarteari ekarpenen bat egin diezaioketela kontsideratzen da, baina soilik normalduta dauden heinean" (Toboso eta Arnau, 2008: 67). Hau da, arreta desgaitasunean jartzen da eta tratamendu soziala jarrera paternalistan oinarritzen da.

2 1/2013 Legegintzako Errege Dekretua, azaroaren 29koa, desgaitasuna duten pertsonen eskubideei eta haien gizarteratzeari buruzko Lege Orokorraren Testu Bategina onartzen duena.
} 
Antzeko garapena izan du desgaitasuna duen pertsonaren kontzeptuak. Antzina erabiltzen ziren hainbat termino atzean utzita ${ }^{3}$, gaur Zuzenbidearen eremuan erabat finkaturik dagoen esamoldea $\mathrm{da}^{4}$. LGDPCD legearen 4. artikuluaren arabera, desgaitasuna duen pertsonatzat hartuko da urritasun fisiko, mental, adimen- edo zentzumen-urritasuna duen edonor, urritasuna ustez iraunkorra izanik eta gizartean osoki eta eraginkortasunez parte hartzea eragozten badio, aldez aurretik administrazioaren aitorpena egon ez arren; eta ondoren eransten du, halakotzat joko direla ere \% 33 ko desgaitasuna edo handiagoa aitortu zaien pertsonak.

Bestalde, nabarmentzekoa da laguntza-behar handienak dituzten pertsona desgaituen taldea 5 . Kolektiboa osatzen dute gutxienez $\% 65$ eko desgaitasun fisiko edo zentzumen desgaitasuna duten pertsonek eta garun paralisia, gaixotasun mentala edo adimen desgaitasuna dutenek \% 33ko maila edo handiagoa badute.

\subsection{Araudia}

Lehenik eta behin, aipatu beharra dago Desgaitasuna duten Pertsonen Eskubideei buruzko Nazio Batuen Nazioarteko Konbentzioak 27. artikuluan aitortzen duela desgaitasuna duten pertsonen gainerakoen baldintza berdinekin lan egiteko eskubidea. Eta ildo beretik doa Europar Batasuna, 2000/78/EE Zuzentarauan enpleguaren esparruan, besteak beste desgaitasun arrazoiengatik diskriminazioaren aurka borrokatzea helburu duena.

Estatu mailako araudiari dagokionez, kolektiboaren lanerako eskubidea arautzen duen arau nagusia 1/2013 Legegintzako Errege Dekretua da, LGDPCD Legea onartzen duena. Arauaren 7.3 artikuluan Herriadministrazioei eskatzen zaie ahalegin berezi bat egitea desgaitasuna duten pertsonek enpleguaren arloan dituzten eskubideak babesteko. Gainera, 13.1 artikuluaren arabera, desgaitasuna duten pertsonei zuzendutako arreta osoa modu honetan ulertu behar dela: “prozesuak edo esku hartzeko neurriak dira, honetara zuzenduak: desgaitasunen bat duten pertsonek garapen-mailarik eta autonomia pertsonalik handiena lortzea; independentziarik handiena eta gaitasun fisiko, mental eta sozialik handiena lortu eta horiei eustea; eta bizitzako alderdi guztietan gizarteratzea eta osoki parte hartzea, bai eta enplegu egoki bat eskuratzea ere”. Eta bigarren atalean dio arreta osoko programetan sartuko dela, besteak beste, lanbide-jarduerarako laguntza.

${ }^{3}$ Hala nola, “minusbalitu” (2273/1985 Errege Dekretuan), "elbarri" edo "urritu".

${ }_{4}$ 39/2006 Legea, abenduaren 14koa, autonomia pertsonala sustatzeari eta mendetasun-egoeran dauden pertsonak zaintzeari buruzkoa, honakoa dio: "lege hau indarrean sartzen denetik, administrazio publikoek egindako xedapen arauemaileetan pertsona horiek aipatzean termino hauek erabiliko da: desgaitasunen bat duen pertsona".

${ }^{5}$ 469/2006 Errege Dekretuaren eta 870/2007 Errege Dekretuaren 3.1. art.
Arauaren 35. artikuluaren arabera, "Desgaitasunen bat duten pertsonek lanerako eskubidea dute, tratu-berdintasunaren eta diskriminaziorik ezaren printzipioen aplikazioa bermatzeko moduko baldintzen arabera, eduki ere". 37. artikuluan, Herriadministrazioak behartzen ditu enplegu-aukerak sustatzera eta enplegua lortu eta mantentzeko beharrezko laguntzak bultzatzera politiken bitartez. Politika hauen xedea izango da, alde batetik, jarduera, enplegu eta laneratzearen tasak handitzea, eta bestetik, enpleguaren kalitatea hobetzea diskriminazioaren aurka gogor ekinez. Gainera, 39. artikuluak ekintza positiboko hainbat teknika zerrendatzen ditu kolektiboaren laneratzea eta aukera-berdintasuna errazteko.

\subsection{Enplegu motak}

Desgaitasuna duten pertsonek bi enplegu motaren bitartez baliatu dezakete lanerako eskubidea: enplegu arrunta, zeinak besteren kontura egindako lana barne hartzen duen (sektore pribatu zein publikoan), enplegu autonomoa eta autoenplegu kolektiboa (lan elkartua); eta enplegu-zentro berezietan enplegua. Enplegu mota horietaz gain, zentro okupazionalen aukera aipatu beharra dago, LGDPCDk 52. artikuluan aurreikusten duena. Hauek lanaren bidezko terapia eskaintzen dute desgaitasuna duten pertsonek ahalik eta garapen pertsonal handiena lor dezaten. Ez da lan harreman bat, baizik eta gizarte zerbitzu bat.

Jarraian, enplegu motak aztertuko dira, banaka eta bakoitzaren ezaugarri nagusiak azalduz.

\subsubsection{Zerbitzu okupazionala}

Zerbitzu okupazionalaren helburu nagusia parte hartzen duten pertsonek ahalik eta garapen pertsonal handiena lortzea da eta, ahal denean, lana eskuratzeko duten gaitasuna eta prestakuntza erraztea. Zerbitzu hauetan parte hartzen duten pertsonek, desgaitasunaren intentsitatea dela eta, ez dira lan egiteko gai. Hori dela eta, ez da lan harreman bat, baizik eta gizarte zerbitzu bat. Kasu batzuetan, desgaitasuna duten langileei ere zuzentzen zaie, baldin eta lan espezifiko batean behar bezala egokitu ez badira edo, okerrera jo badute, zerbitzu okupazionalean eskaintzen den terapia gomendagarria bada (LGDPCD 52. art.).

Gizarteratzea eta laneratzea sustatzen duen euskal ereduak, desgaitasuna duten pertsonak gizartezerbitzuen sistema pasiboetatik enplegu-politika aktiboetara pasatzea errazten du, bakoitzaren beharretara egokitzen den ibilbide pertsonalak diseinatzen baititu. Euskadiren esperientziak erakusten du ona dela zerbitzu okupazionalaren eredua eta enplegu-zentro berezietako enpleguaren eredua elkarrekin bizitzea, izan ere, pertsona askorentzat segurtasuna ematen duen ingurune ezagunak dira. Gainera, azpimarratu beharra dago 


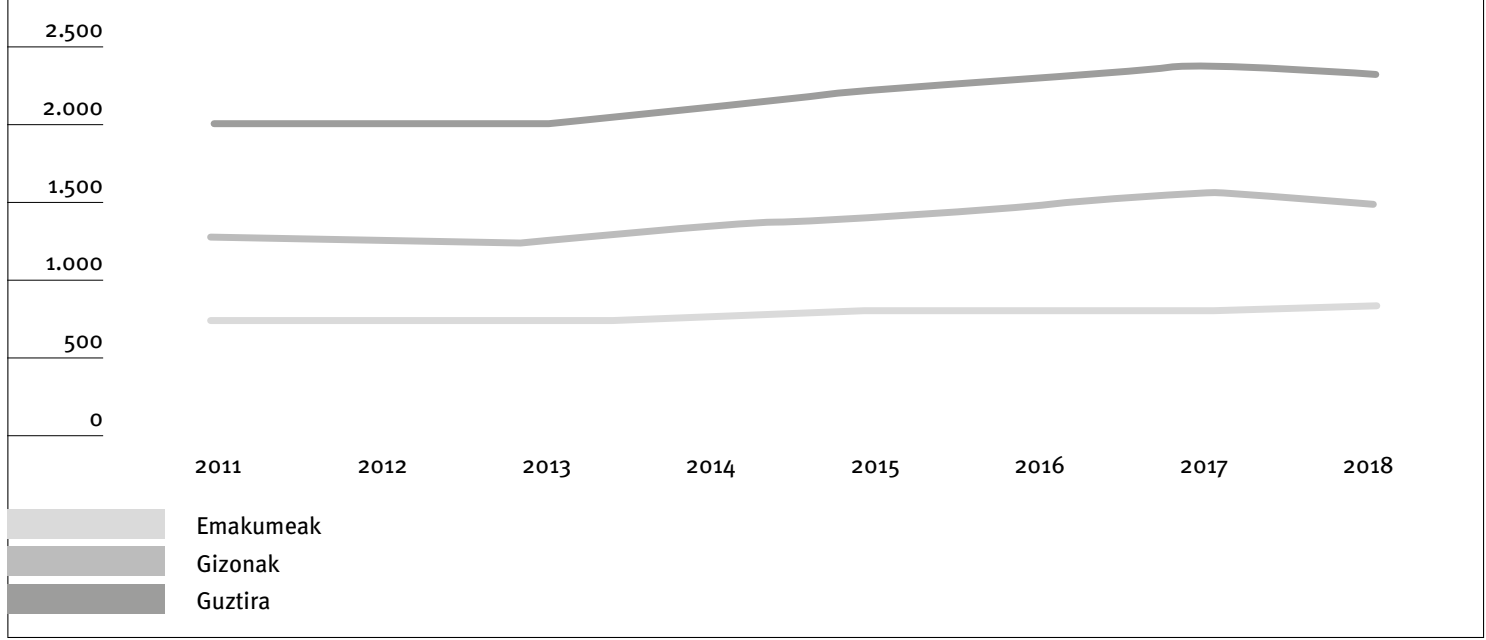

Iturria: Gizarte Ekonomiako Euskal Behatokiak egindakoa, EHLABEren datuak oinarri hartuta.

egun enplegu-zentro berezietan lana duten adimen desgaitasuna duten pertsona gehienak zerbitzu okupazionaletik datozela ${ }^{6}$.

1. grafikoa oinarri hartuta, azpimarratzekoa da azken urteetan etengabe hazi dela zerbitzu okupazionala, 2018an ia 2.400 pertsona zerbitzu okupazionalen batean egoteraino. Igoeraren arrazoiak bi dira, batetik, emakumeen igoera jarraitua, eta bestetik, zerbitzu okupazionalean dauden gizonen igoera handiagoa. Ikus daitekeenez, bi sexuen arteko aldea handiagoa izan da.

\subsubsection{Enplegu-zentro bereziak}

Enplegu-zentro bereziak desgaitasuna duten pertsonei enplegua eskuratzea errazten dien tresna nagusia dira. 1/2013 Legegintzako Errege Dekretuak 43. artikuluan definitzen ditu juridikoki, eta honela dio:

Enplegu-zentro bereziak dira merkatuoperazioetan ohikotasunez parte hartuz ondasunak edo zerbitzuak produzitzeko jarduera batean aritzea izanik xede nagusia, desgaitasunen bat duten pertsonentzat enplegu ordaindu bat ziurtatzeko helburua dutenak; aldi berean, bitarteko bat dira ahalik eta era horretako pertsona gehien ohiko enplegu-erregimenera biltzeko. Era berean, enplegu-zentro bereziek, laguntzako unitateen bitartez, desgaitasunen bat duten langileen egokitze pertsonala eta soziala lortzeko behar dituzten doikuntza-zerbitzuak eskaini behar dituzte, kasuan kasuko egoeraren arabera eta erregelamenduz ezarritakoari jarraituz.
Helburu nagusia da enplegagarritasunerako zailtasun bereziak dituzten pertsonei ordaindutako enplegu produktibo bat bermatzea, eta aldi berean, enplegu arruntera igarotzea ahalbidetzea.

Erakunde mota hauen oinarrizko alderdiak aztertuko dira, abenduaren 4ko 2273/1985 Errege Dekretuak arautzen dituena. Hauen 2. artikuluaren arabera, enplegu-zentro bereziak ondasunak eta zerbitzuak produzitzeko jarduerak egiten dituzten enpresak dira, jarduera-adarra edozein dela, eta merkatuan ohikotasunez lehiatzen dira. Eta 9. artikuluak gaineratzen du, sektore berean aritzen diren gainontzeko enpresen arau eta betekizun berdinen menpe egongo direla.

LGDPCDren 43. artikuluak enplegu-zentro bereziek bete behar dituzten derrigorrezko bi betekizunak zehazten ditu. Alde batetik, langileetatik \% 70 gutxienez desgaitasunen bat duten pertsonak izango dira, honen barnean egongo direlarik \% 33ko desgaitasuna edo handiagoa aitortu zaien langileak. Bestetik, langileek behar dituzten egokitze pertsonal eta sozialeko zerbitzuak eman beharko dituzte berariaz sortutako laguntza-unitateen bitartez.

Enplegu-zentro berezi mota ezberdinak daude, baina artikulu honetan Gizarte-ekimeneko enpleguzentro bereziak bakarrik aztertuko ditugu, lehen aipatutako 43. artikuluari berriki egin zaion aldaketan oinarritzen dena. Gainera, esan beharra dago Gizarteratu eta Laneratzeko Euskal Eredua soilik gizarte-ekimenekoak diren enplegu-zentro bereziak osatzen dituztela. Sektore Publikoko Kontratuen Legearen ${ }^{7}$ onarpenaren ondorioz 4 . atal bat gehitu zitzaion 43 artikuluari, honek lehengo aldiz definitzen ditu mota honetako erakundeak gure ordenamenduan, eta honakoa xedatzen du: 
Gizarte-ekimeneko enplegu-zentro berezitzat hartuko dira artikulu honen 1. eta 2. apartatuetan ezarritako baldintzak betetzen dituzten eta irabazi asmorik gabekoa izan edo bere estatutuetan izaera soziala aitortua duen entitate batek edo batzuek zuzenean edo zeharka sustatuak direnak eta zentroaren ehuneko 50 baino gehiagoko partaidetza dutenak, elkarteak izan, fundazioak izan, zuzenbide publikoko korporazioak izan, gizarte-ekimeneko kooperatibak izan edo ekonomia sozialeko bestelako entitateak izan; bai eta merkataritza-sozietateen titulartasunekoak direnak ere, baldin eta sozietate horietan kapital sozialaren gehiengoa aurrez aipatutako entitateren baten jabetzakoa bada, dela zuzenean, dela zeharka Merkataritza Kodearen 42. artikuluan araututako sozietate nagusiaren kontzeptuaren bitartez. Baina kasu guztietan, estatutuetan edo akordio sozialean beren burua behartuko dute haien guztizko etekinak berriz inbertitzera desgaitasuna duten pertsonentzat enplegu-aukerak sortzeko eta beren lehiakortasuna eta ekonomia sozialeko jarduera etengabe hobetzeko, eta aukeratu ahalko dute enplegu-zentro berezian bertan berriz inbertitzea edo gizarte-ekimeneko beste enplegu-zentro berezi batzuetan berriz inbertitzea.

Aldaketa honek, aurrerapauso handi bat suposatu zuen Gizarte-ekimeneko enplegu-zentro berezientzat, eta zehazki, Laneratzeko eta Gizarteratzeko Euskal Eredua osatzen duten erakundeentzat.

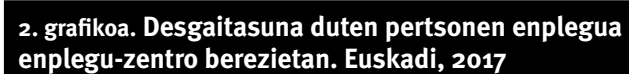
enplegu-zentro berezietan. Euskadi, 2017

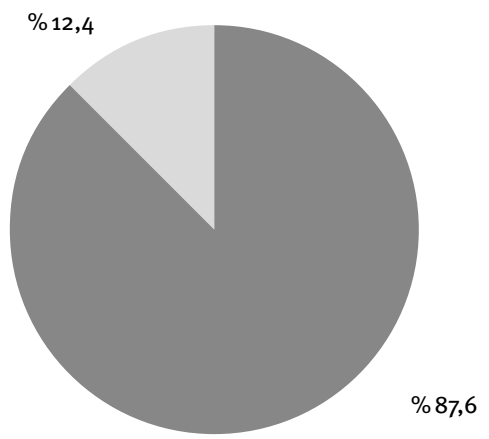

Gizarte-ekimeneko enplegu-zentro berezietan Gainontzeko enplegu-zentro berezietan
2. grafikoaren datuen arabera, argi dago EAEko pertsona desgaituen gehiengoa gizarte-ekimeneko enplegu-zentro berezi batean aritzen dela. 2017 urtean, ia 9.000 pertsona zeuden guztira enpleguzentro berezietan, eta horietatik ia \% 88 gizarteekimeneko enplegu-zentro berezi batean.

Enplegu arruntari buruzko puntua garatu baino lehen, komeni da gogoraraztea enplegu-zentro berezien helburu nagusietako bat desgaitasuna duten pertsonen enplegu arrunterako igarotzea erraztea dela. Pertsona hauek lan-merkatu arruntean sartzea bultzatzeko sortu ziren, hau da, igarobide gisa; eta honegatik leku garrantzitsua izan dute kolektiboaren gizarteratu eta laneratzeko politiketan.

Esan bezala, azken helburua enplegu arruntera igarotzea da, baina igarobide hori ez da derrigorrezkoa izan behar, baizik eta langileak duen aukera bat izan behar du bere jarduera non garatu askatasunez aukeratzeko. Honen harira, Desgaitasuna duten Pertsonen Eskubideei buruzko Nazio Batuen Nazioarteko Konbentzioak 27.1 artikuluan dioenez, desgaitasuna duten pertsonek beren bizimodua ateratzeko eskubidea egikarituko dute askatasunez aukeratutako lanaren bidez, irekiak, inklusiboak eta irisgarriak diren lan-merkatu eta inguruetan, edozein enplegu motan diskriminazioa debekatuz, eta gainerako pertsonen aukera berdinekin. Beraz, edozein langilek eskubidea izango du bere lanbide-jarduera garatu nahi duen lan-ingurunea aukeratzeko, askatasunez eta baldintza berdinekin, eta ezingo da inongo arrazoirengatik diskriminatu eta baztertu. Aukera berdintasunak eta diskriminazio ezak berekin ekarriko lukete xedeetako bat enplegu arruntera igarotzea izatea, non taldearentzat oztopo gehiago dauden.

Euskadiko enplegu-zentro bereziak sortu zirenetik, desgaitasuna duten pertsonak lan-merkatu arruntean sartzea gauzatzeko lanean ari dira. Datuek erakusten dute enplegu-zentro berezietako enplegutik enplegu arruntera igarotzeak ahalegin handia eskatzen duen prozesua dela. Eta datuek hori adierazten dute, ikus 1. taula.

Iturria: Egileak egindakoa, Gizarte Ekonomiako Euskal Behatokiak, Lanbidek eta EHLABEK emandako datuetan oinarrituz.

1. taula. Gizarte-ekimeneko enplegu-zentro berezietako enplegutik enplegu arrunterako igarobidea, desgaitasun motaren arabera. Euskadi, 2015-2018.

\begin{tabular}{|l|c|c|c|c|}
\hline Urtea & Adimen desgaitasuna & Desgaitasun fisikoa & Zentzumen desgaitasuna & 0 \\
\hline 2015 & 35 & 14 & 1 & 49 \\
\hline 2016 & 22 & 14 & 9 & 37 \\
\hline 2017 & 62 & 19 & 90 & 0 \\
\hline 2018 & 32 & 96 & 10 & 217 \\
\hline $2015-2018$ & 151 & 56 & 2 & 21 \\
\hline
\end{tabular}

Iturria: Gizarte Ekonomiako Euskal Behatokiak egindakoa, EHLABEren datuak oinarri hartuta. 
Azken lau urteetan 217 pertsona igaro dira EHLABEri ${ }^{8}$ atxikitako gizarte-ekimeneko enplegu-zentro berezi bateko enplegutik enplegu arrunt batera. Hots, bataz beste, urtero, ia 55 pertsona desgaitu sartu dira lanmerkatu arruntean. Igarotzea egin dutenen ehunekoa oso txikia bada ere, igarobide horren alderdi batzuek balioa eransten diote gizarte-ekimeneko enplegu-zentro berezi hauek egiten duten lanari. Datuek erakusten dute, erakunde hauek garrantzizko ekarpena egiten dutela desgaitasuna duten pertsonentzat aukerak sortzeko orduan, eta gainera, igarotzearen helburuari garrantzi handia ematen zaiola, nahiz eta bere irismena mugatua izan.

\subsubsection{Enplegu arrunta}

Enplegu arrunta da besteen kontura egiten dena enpresa pribatu zein Herri-administrazioetan, enplegu autonomoa eta autoenplegu kolektiboa. Enplegu pribatuari dagokionez, LGDPCDren 42. artikuluak desgaitasuna duten pertsonentzat gorde beharreko lanpostuen kuota ezartzen du, eta 50 langile baino gehiago duten enpresetan, langileen $\% 2$ gutxienez desgaitasunen bat izan beharko du.

Estatistika Institutu Nazionala (INE) datuen arabera, Euskadiko Autonomia Erkidegoan desgaitasuna duten 8.000 pertsona inguruk egiten dute lan besteren kontura merkatu arrunt pribatuan. Honek lan egiten duten pertsona desgaituen totalaren $\% 33$ suposatzen du. Konparaketa bat egiteko, nabarmendu nahi dugu enplegu-zentro berezietako enplegua zifra hori baino altuagoa dela $(\% 36)$.

Enplegu publikoaren kasuan, EPOE/EBEP` legearen 59. artikulua izan behar da kontutan, bi puntu garrantzitsu zehazten dituelarik. Batetik, "bete beharreko lanpostuen ehuneko zazpiko kupoa gordeko da gutxienez, desgaitasunen bat duten pertsonek bete ditzaten, betiere, hautaketaprozesuak gainditu, desgaitasuna egiaztatu eta desgaitasun hori bete beharreko zereginekin bateragarri dela erakutsita, horrela, aria-arian, administrazio publiko bakoitzak dituen langile guztien ehuneko bira iritsi arte". Eta bestetik, "Herriadministrazioari dagokionez, "hartu beharreko neurriak hartuko ditu hautaketa-prozesuan denborak eta bitartekoak arrazoizkoa den eran moldatzeko eta egokitzeko, eta, behin prozesu hori gainditutakoan, dagokion lanpostua desgaitasuna duen pertsonaren beharrizanei egokitzeko".

EAEko datuei dagokionez, kalkulatzen da 2016. urtean desgaitasuna zuten ia 5.000 pertsona aritzen zirela enplegu publikoan, hau da, lurraldean lan egiten zuten pertsona desgaituen kopuru totalaren $\% 20$ gutxi gorabehera.

${ }^{8}$ Euskal Herriko Lan Babestuaren Elkartea, desgaitasunak dituzten pertsonen gizarte- eta lan-txertatzea sustatzen duten irabaziasmorik gabeko erakundeen euskal elkartea da.

${ }^{9}$ 5/2015 Legegintzako Errege Dekretua, urriaren 3oekoa, Enplegatu Publikoaren Oinarrizko Estatutuaren Legearen testu bategina onartzen duena.
Enplegu autonomoari dagokionez, LGCPCDren 47. artikulura jo behar da. Honen arabera, "botere publikoek, zeinek bere eskumenen eremuan, desgaitasunen bat duten pertsonen lan autonomoa sustatzeko politikak onartuko dituzte, betiere ekimen ekonomiko eta profesionalak abiarazi eta garatzeari begira, diren norbere konturakoak edo ekonomia sozialeko erakundeen bitartekoak”. Kasu honetan, errealitate zail baten aurrean gaude, ez baita erraza autonomo moduan lan egiten hastea eta honen adierazgarri dira datuak, izan ere, desgaitasuna duten pertsonen enplegu autonomoa Euskadin 2.600 pertsona ingurukoa izango litzateke.

Azkenik, enplegu elkartua aipatu beharra dago, hau da, kooperatibetan eta lan-sozietateetan burutzen dena. Figura hau gutxi erabili da orain arte, hala ere, azken urteetan gero eta gehiago ari da honen alde apustu egiten.

\section{Gizarteratu eta Laneratzeko Euskal Eredua}

Euskal Autonomia Erkidegoko Gizarteratu eta Laneratzeko eredua osatzen duten erakundeak Euskal Herriko Lan Babestuaren Elkartean (EHLABE) biltzen dira. Desgaitasunen bat duten pertsonak gizarteratu eta laneratzea sustatzen duten irabazi asmorik gabeko erakundeen euskal elkarte hau 1987an sortu zen eta azken 30 urte hauetan EAEn lan egiten duten gizarte-ekimeneko enplegu-zentro berezi publiko ia guztiak bildu ditu ${ }^{10}$. Hau da, EAEko enplegu-ekimen guztien \% 95 biltzen du. EHLABEren datuen arabera, 14 erakundek, 100 lantokik baino gehiagok eta desgaitasuna duten 10.000 pertsona baino gehiagok osatzen dute eredua.

Erakunde guzti hauek oinarrizko helburu komuna dute. Batetik, lanaren balioa gizarteratzeko bitarteko gisa, hau da, desgaitasuna duten pertsonentzat kalitatezko enplegua sortzea. Bestetik, denek partekatzen dituzte gizarte ekonomiaren printzipio orientatzaileak ${ }^{11}$.

${ }_{10}$ Gizarteratu eta Laneratzeko Euskal Eredua osatzen duten erakunde guztiak gizarte-ekimeneko enplegu zentro bereziak dira.

${ }^{11}$ Gizarte Ekonomiako 5/2011 Legeko 4. artikulua:

a. Kapitalaren gainetik pertsonak eta gizarte helburua nagusitzea. Hori kudeaketa autonomo eta garden, demokratiko eta parte hartzailean zehazten da. Ondorioz, erabakiak hartzeko garaian, gizarte-kapitalari egindako ekarpenak baino gehiago, pertsonak eta erakundeari emandako zerbitzuak eta lanean egindako ekarpena, edo gizarte-helburua hartzen dira kontuan.

b. Jarduera ekonomikotik lortutako emaitzak, batez ere, bazkideek edo bertako kideek egindako jarduera edo zerbitzuaren eta eskainitako lanaren eta, hala badagokio, erakundearen xede den gizarte-helburuaren arabera aplikatzea.

c. Tokiko garapenarekin konpromisoa, gizonen eta emakumeen arteko aukera-berdintasuna, gizarte-kohesioa, gizarte-bazterketa jasateko arriskua duten pertsonen gizarteratzea, enplegu egonkorra eta kalitatezkoa sortzea, norberaren, familiako eta laneko bizitza bateragarri egitea eta jasangarritasuna lagunduko duen barruko eta gizartearekiko elkartasuna sustatzea.

d. Botere publikoekiko independentzia. 
Euskal eredua erreferente bihurtu da desgaitasuna duten pertsonen laneratzean, bai estatu mailan, bai Europa mailan ere. Eredu honek pertsonen gaitasunak eta hauen garapena ditu helburutzat, ingurune profesional eta lehiakorretan lan-aukerak sortuz. Laguntza-behar handienak dituzten pertsonak lehenesten dituzte, eta lan ibilbide osoa ikuspegi inklusibo batekin gauzatzen da. Lehen esan bezala, helburu nagusia izan da kolektiboa lan-merkatu arruntean sartzen laguntzea enplegu lagunduaren bitartez, hori dela eta, pertsona bakoitzaren beharrei egokitutako ibilbide pertsonalak kudeatzen dituzte.

Puntu honetan, beharrezkoa da euskal ereduaren ezaugarri nagusienak aztertzea (Moratalla, 2017: 136):

- Desgaitasuna duten pertsonen enplegagarritasunari zuzendutako hainbat programa kudeatzen dituzte eta laneratzeko ibilbide osoak dituzte (lanbide-orientazioa, formakuntza, lan-bitartekaritza, etab.). Horretaz gain, Herri-administrazioekin, elkarte-sarearekin, enpresekin eta pertsonekin estuki egiten dute lan.

- Lan-ibilbideak diseinatzen dituzte, ikuspegi inklusibo batekin eta pertsona bakoitzaren behar eta nahietara egokituta. Horrela, enplegu-politika aktiboetara pasatzea errazten da.

- Honengatik guztiarengatik eredu malgu eta berritzailetzat jotzen da, zeinak pertsonaren gaitasunak indartzea bilatzen duen.

- EHLABEko enplegu-zentro bereziek baldintzaberdintasunean burutzen den eta inklusiboa, irekia eta irisgarria izango den enplegu baten alde egiten dute lan. Horretarako, hainbat enplegagarritasun-zerbitzu dituzte. Zerbitzu hauek desgaitasuna duten pertsona jartzen dute erdigunean, zailtasun handienak dituzten pertsonak bereziki. Zerbitzu hauen helburua da pertsona bakoitzak askatasunez aukeratutako lan baten bidez bizimodua ateratzeko aukera izatea. Ondorioz, pertsonak erdigunean jartzen dituen eredua da.

- Ingurune lehiakor eta profesionaletan enpresajarduera mota desberdinak kudeatzerakoan bikaintasuna lortzeko helburuarekin egiten dute lan, eta kudeaketa honi esker milaka enplegu sortu dituzte pertsona desgaituentzat sektore desberdinetan. Desgaitasuna duten pertsonek lan desberdinak egiteko gaitasuna dutela erakutsi dute.

- Azkenik, azpimarratzekoa da gizarte-ekimeneko enplegu-zentro berezien, Herri-administrazio eskudunen eta eragile, publiko, ekonomiko eta sozialen arteko sareko lana eta koordinazioa.

Ondoren, Euskal Herriko Lan Babestuaren Elkartean biltzen diren gizarte-ekimeneko enplegu-zentro berezien bereizgarri garrantzitsuenak azpimarratu behar dira:

- Lanak duen balioa desgaitasuna duten pertsonak gizarteratzeko. Horrela, gizarteratze osoa lortzeko prozesuetan tresna garrantzitsuena bihurtu da.
- Kudeaketaren funtzionamendua, desgaitasuna duten pertsonei enplegagarritasun-zerbitzuak eskainiz sektore desberdinetan lan egiteko aukerekin.

- Desgaitasuna duten pertsonek ibilbideen antolaketan eta kudeaketan parte-hartzea, laguntza-behar handienak dituzten pertsonak lehenetsiz.

- Euskal gizarteak duen kultura ekintzaile indartsua. Nabarmentzekoak dira jarduerak eta zerbitzuak abian jartzeko orduan eta hauek egokitzeko orduan erabiltzen diren jardunbide berritzaileak.

- Eragile publiko, ekonomiko eta sozialekin eta Herri-administrazioekin koordinazioa.

- Eragile desberdinekin sarean egiten den lana.

- Diru-laguntza eta laguntza publikoek duten egonkortasuna.

- Autofinantzaketa handia dutenez eta soberakinen berrinbertsioa ere altua denez, jasangarritasuneta sendotasun-finantzarioak lortu dituzte eta honek ekimen berriak abian jartzeko aukera eman die.

- EHLABEn biltzen den oinarri asoziatibo sendoa eta lurraldean sustraitua dagoena.

\section{Desgaitasuna duten pertsonen eskubideei buruzko nazioarteko konbentzioa}

2006ko abenduaren 13an Nazio Batuen Batzarrak Desgaitasuna duten Pertsonen Eskubideei buruzko Konbentzioa onartu zuen. XXI. mendeko giza eskubideen lehenengo Ituna izan zen eta ikuspegi aldaketa suposatu zuen desgaitasuna duten pertsonei dagokionez. Konbentzioa garapen sozialaren eta gizarte inklusiboaren aldeko tresna bezala sortu zen. Bertan berretsi egiten da edozein desgaitasun mota duten pertsona guztiek giza eskubide eta oinarrizko askatasun guztiez gozatzeko aukera izango dutela.

Konbentzioak inklusioari lotutako ikuspegi berri bat proposatzen du, desgaitasuna eredu sozialetik eta giza eskubideen ikuspegitik begiratzea. Hots, eredu honek kontsideratzen du desgaitasuna egoera bat dela eratorri dena gizarteak dituen mugetatik desgaitasuna duten pertsonen beharrizanak gizartearen antolaketaren barruan kontuan hartzen direla bermatzeko, eta helburua gizartearen "normalizazioa" izango da, pertsona guztien beharrizanei aurre egin ahal izateko (Toboso eta Anau, 2008). Hori horrela, Konbentzioa asmo honekin jaio zen: "sustatzea, babestea eta ziurtatzea desgai diren pertsona guztiek oso-osoan eta berdintasun-baldintzetan izatea oinarrizko eskubide eta funtsezko askatasun guztiak"(1. art.).

Enpleguari dagokionez, Konbentzioaren 27. artikulura jo behar dugu, honakoa xedatzen duena: 
1. Estatu alderdiek aitortzen dute pertsona desgaituek duten eskubidea lan egiteko, gainerakoen baldintza berberetan; horrek berarekin dakar eskubidea, bizimodua ateratzeko aukera izan dadin, askatasunez aukeratu edo onartutako lanaren bidez, pertsona desgaituentzako irekiak, integratzaileak eta eskuragarriak diren lan-merkatu eta -inguruetan. Estatu alderdiek babestu eta sustatuko dute lan egiteko eskubidearen egikaritza, baita enpleguak iraun bitartean desgaitasunen bat jasaten duten pertsonen kasuan ere, neurri egokiak hartuz, legeria ematea barne; neurri horien artean izango dira:

a. Desgaitasun-arrazoien ondoriozko bereizkeria debekatzea, edozein enplegu-motaren inguruko arazo guztiei dagokienez, horien artean direla hautatze-, kontratazio- eta enplegu-baldintzak, enplegu-jarraitutasuna, lanbide-aurrerakuntza eta lan-baldintza seguru eta onuragarriak;

b. pertsona desgaituen eskubideak babestea, gainerakoen baldintza berberetan izan ditzaten lan-baldintza bidezko eta mesedegarriak, eta bereziki aukera- eta ordainsari-berdintasuna;

c. balio bera duen lana egiteagatik, lan-baldintza seguruak eta onuragarriak, jazarpenaren aurkako babesa barne, eta jasandako kalteengatiko konponketak;

d. ziurtatzea pertsona desgaituek lan- eta sindikatu-eskubideak egikari ahal izatea, gainerakoen baldintza berberetan;

e. ahalbidetzea pertsona desgaituek eragingarritasunez eskura izatea orientazio teknikoko eta bokazio-orientazioko programa orokorrak, kolokazio-zerbitzuak eta lanbideprestakuntza nahiz etengabeko prestakuntza;

f. bultzatzea pertsona desgaituen enpleguaukerak eta lanbide-aurrerakuntza lanmerkatuan, eta pertsona horiei laguntzea, enplegua bilatzeko, lortzeko edo enpleguari eusteko, eta berriro lanean hasteko;

g. aukerak sustatzea, enpresei dagokienez, eta beregaineko enplegua sortzeari, kooperatibak eratzeari eta negozio berriei ekiteari dagokienez;

h. pertsona desgaituak sektore publikoan enplegatzea;

i. sektore pribatuan pertsona desgaituen enplegua sustatzea, egoki diren politika eta neurrien bidez, bere baitara bil ditzaketenak afirmazio-ekintzako programak, pizgarriak eta bestelako neurriak;

j. lan egiteko lekuan pertsona desgaituentzako zentzuzko egokitzapenak egiten direla zaintzea;

k. pertsona desgaituek lan-merkatu irekian lanesperientzia har dezatela sustatzea;

l. pertsona desgaituei zuzendutako programak sustatzea, bokazio- eta lanbide- birgaikuntzarako, enpleguari eusteko eta lanean berriro hasteko.

2. Estatu alderdiek ziurtatuko dute pertsona desgaituek ez jasatea esklabotza eta morrontzarik, eta babesa izatea, gainerakoen baldintza berberetan, derrigorreko edo nahitaezko lanaren aurka.

Eredu honen arabera, desgaitasuna duten pertsonek enplegua lortzeko dituzten zailtasunak elkarrekintza baten emaitza dira, pertsona hauen ezaugarrien eta enpleguan bereziki dauden oztopoen arteko elkarrekintza hain zuzen ere.

Konbentzioaren 27. artikuluaren arabera, desgaitasuna duten pertsonek lan egiteko eta bizimodua ateratzeko eskubidea dute besteen baldintza berdinetan, askatasunez aukeratutako lan baten bitartez. Eta adierazten du herrialdeek beharrezko neurriak hartu beharko dituztela enpleguari lotutako gaietan diskriminazioa debekatzeko eta eskubideak babesteko. Helburu hauek lortzeko, xedapen honek hainbat betebehar eta tresna zehazten ditu.

Puntu honetan, Gizarteratu eta Laneratzeko Euskal Eredua Konbentzioaren 27. artikuluarekin zein puntutaraino dagoen lerrokatuta aztertzen saiatuko gara. Modu honetan, bi ereduen artean dagoen lotura identifikatu ahal izango da. Lehendabizi, NBEren Itunak aipatzen duen lan-ingurune ireki, inklusibo eta bereizkeriarik gabekoa aztertu beharra dago. Ondoren, bi ereduak puntuka alderatuko ditugu.

Lan-ingurune ireki batean ezin da inor kanpoan utzi inolako arrazoirengatik. Horretarako, oztopoak kendu eta lan-inguruneak egokitu behar dira. Desgaitasuna duten pertsonek lan-merkatuan baldintza berdinetan sartzea eragozten dieten oztopoekin aurkitzen dira. Gizarteak oztopo horiek existitzea eragozteko duen ezintasunaren emaitza dira. Beraz, gizartea da egokitu behar dena, pertsona guztientzat irisgarria eta inklusiboa izateko.

Bestalde, lan-merkatua inklusiboa izateko, beharrezko da gizarte-eredua ere inklusiboa izatea. Horretarako, kolektiboaren eskubideekin zerikusia duten neurriak hartu beharko dira, hala nola, enplegu-politika aktiboak edota enplegatzaileek neurri eraginkorragoak hartzea.

Bereizkeriarik gabeko inguruneari dagokionez, lanmerkatu inklusibo eta irekia ezin da diskriminatzailea izan, horretarako, sektore pribatuan enplegua sustatu beharko da, eta Herri-administrazioek kolektibo honen kontratazio eta enplegua sortzea bultzatu beharko dute enplegu-politika aktiboen bitartez. Gizarteratu eta Laneratzeko Euskal Ereduak Konbentzioarekin bat egiten du helburuan, hau da, lan-ingurunea eta enplegua inklusiboa, irekia eta irisgarriak izan behar dira, gainerakoen baldintza berdinetan. Horretarako, EHLABEko entitateek enplegagarritasunerako zerbitzu eta programa desberdinak kudeatzen dituzte. Enplegagarritasuna 
hobetzera bideratutako zerbitzuak dira ${ }^{12}$ eta helburu garrantzitsu bat dute: pertsonek euren ibilbidea erabaki ahal izatea eta askatasunez aukeratutako lan bat izatea. Eredu honek pertsonaren gaitasunak indartzea bilatzeaz gain, kolektiboa enplegu-politika aktiboetara pasatzea errazten du, azken helburua izanik lan-merkatu arruntera igarotzea.

Euskal eredua inklusiboa da, pertsona eta bere garapena erdigunean jartzen dituelako. Gainera, ingurune oso lehiakor eta profesionaletan enpresajarduera mota desberdinak kudeatzen dituzte, sektore ezberdinetan lan egiteko duten gaitasuna erakutsiz eta lan-esperientzia handia eskuratuz. Beste ezaugarri garrantzitsu bat da eragile publiko, sozial eta ekonomiko ezberdinekin egiten den lana, koordinatua eta sarean ${ }^{13}$. Hauen laguntzarekin pertsona bakoitzarentzako lan eta gizarte ibilbideak kudeatu, babestu eta osatzen dira.

Puntu honetan, esan genezake Euskal Eredua osatzen duten gizarte-ekimeneko enplegu-zentro bereziek desgaitasuna duten pertsonen lan-garapenerako ingurune egoki bat sortu dutela, inklusiboa, irekia eta irisgarria dena, non pertsonek askatasunez erabakitzen duten egin nahi duten lana. Bigarrenik, eta lehen esan bezala, kolektiboaren lan egiteko eskubidearen erabilera babestu eta sustatzeko 27. artikuluak proposatzen dituen neurriak aztertuko ditugu, Gizarteratu eta Laneratzeko Euskal Ereduaren ikuspegitik.

27.1 artikuluko a), b) eta c) puntuek diskriminazioa debekatzeko, desgaitasuna duten pertsonen eskubideak gainontzekoen baldintza berdinetan babesteko, eta taldearen sindikatu-eskubideak bermatzeko neurriak aipatzen dituzte. Lehenengo bi puntuei dagokienez, EHLABEko entitateek, enplegagarritasunerako kudeatzen dituzten zerbitzuak, espezializatutako eta egokitutako zerbitzuak dira, eta honi esker, gainontzekoen baldintza berdinetan sartu daitezke enplegubideetan. Hirugarren puntuari dagokionez, gizarteekimeneko enplegu-zentro berezi gehienek dituzte hitzarmen kolektibo propioak eta sindikaturik daude.

27.1.d) puntuak lanbide-orientazioko eta lanbideformakuntzako programetan sartzeari buruz hitz egiten du. Orientazioari dagokionez, OrientazioUnitate espezializatuak daude ibilbideko fase guztietan. Eta formakuntzaren kasuan, formakuntza espezializatua, egokitua eta kualifikatua eskaintzen da enplegagarritasuna hobetzen eta kalitate oneko enplegua lortzen laguntzeko.

e) puntuak lan-merkatuan dauden enplegu-aukerei buruz hitz egiten du, eta enplegua bilatzeko, lortzeko edo enpleguari eusteko eman beharreko sostenguari

${ }_{12}$ Zerbitzu hauen artean, lanbide-orientazio espezializatua, lanbitartekaritza eta desgaitasuna duten pertsonentzat egokitutako formakuntza (ikus 〈http://www.ehlabe.eus〉).

${ }^{13}$ Herri-administrazioak, Euskadiko Hirugarren Sektorea, gizarte-eragile tradizionalak, Unibertsitateak, gizarte-zerbitzuak, osasun mentaleko zentroak, etab. buruz ere aritzen da. Honen harira, lehen aipatu ditugun alor guztien arteko koordinazioari eta elkarlan estuari esker, eta pertsona bakoitzarekin koordinazioan ere, igarobidea egiteko eta hobetzeko aukerak sortzen doaz. Gainera, euskal eredua desgaitasuna duten pertsonak lan eta gizarte ibilbide osoan zehar laguntzean datza nagusiki.

Konbentzioaren f) puntuak norbere kontura egindako enplegua sortzeari buruz, kooperatibak eratzeari buruz eta enpresa propioak ekiteari buruz hitz egiten du. EHLABEko entitateek, gizarte ekonomiaren parte diren heinean, parte hartzeko kultura sendoa dute eta, ondorioz, desgaitasuna duten pertsonen parte-hartze aktiboa sustatzen dute entitatearen barruan. Bestalde, formakuntza-programak kolektibo hau ingurune arruntean sartzera zuzenduta daude. Ingurune honetan aukeratu ahalko dute burutu nahi duten enplegu mota, esaterako enplegu autonomoa edo enplegu elkartua, besteak beste.

g) eta h) puntuek sektore publikoan zein pribatuan enplegua sustatzearen garrantzia azpimarratzen dute. Lehen esan bezala, enplegu arruntera igarotzea da azken helburua, betiere kontuan izanik pertsona bakoitzaren beharrak, iritzia, eta gaitasunak. Prozesu honetan laguntzeko, eta bereziki laguntza-behar handienak dituzten pertsona desgaituentzat, enplegu lagunduaren metodologia erabiltzen da. Bestalde, azken urteetan, euskal Herri-administrazioekin lankidetzan, adimen desgaitasuna duten pertsonak enplegu publikoan sartzea hobetzeko lanean ari dira.

Arauaren i) puntuak dio beharrezkoa dela zentzuzko egokitzapenak egiten direla zaintzea. Hau euskal ereduaren oinarrietako ba da, eta arautegiak enplegu-zentro bereziak behartzen ditu desgaitasuna duten pertsonei egokitze pertsonal eta sozialak eskaintzera ${ }^{14}$. Historikoki, izaera berritzailea duten ekintza eta praktikak sartzen eta abian jartzen joan dira, pertsona bakoitzaren gaikuntza eta gaitasunak hobetzen laguntzeko, lanpostuaren eskakizunen eta pertsonen gaitasunen arteko etena txikitzeko asmoz.

Azkenik, artikuluko j) eta k) puntuek xedatzen dute lan-esperientzia hartzea sustatu behar dela eta bokazio eta lanbide birgaikuntzarako programak ere bultzatu behar direla. Euskal ereduko erakundeetan aritzen diren desgaitasuna duten pertsonek lanesparru desberdinetan eskuratzen dute esperientzia. Gainera, laguntzaren eta orientazio eta formakuntza programen bitartez, beharrezkoa suertatzen den kasuetan enpleguari eustea eta lanean berriro hastea ahalbidetzen dute.

Azterketa honen ondoren, ondorioztatu dezakegu Gizarteratu eta Laneratzeko Euskal Eredua NBEren Nazioarteko Itunak defendatzen duen lan inguruaren adibide argia dela, desgaitasuna duten pertsonek askatasunez eta gainontzekoen baldintza berdinetan aukeratzen duten enplegua burutzeko ingurune egoki bat eraikitzea lortu baitute.

${ }^{14}$ LGDPCDren 43. artikuluan. 


\section{Ondorioak}

Artikuluan zehar, desgaitasuna duten pertsonen gizarteratzean enpleguak duen garrantzia azpimarratu da, zeinak inklusioa, integrazioa eta autonomia ematen dien. Euskadiren kasuan, enpleguak funtsezko paper bat betetzen du, Gizarteratu eta Laneratzeko Euskal Ereduan barneratzen diren entitateek lan gogorra egin dute kolektiboaren enplegu duina eta kalitate onekoa izateko. Eguneroko lan honi esker, gure lurraldeko eredua erreferente bilakatu da Europa mailan, eta honetan hainbat faktorek lagundu dute.

Etorkizunari begira hainbat erronka dituzte Euskadiko gizarte-ekimeneko enplegu-zentro bereziek, oraindik lan handia egin beharra baitago enpleguaren arloan, enplegu gehiago eta hobea lortu ahal izateko, bereziki laguntza behar handienak dituzten pertsonentzat. Ondorioz, interesgarria izango litzateke Euskal Ereduaren arrakastak eta erronkak ondorioetara ekartzea. Arrakastei dagokienez, Gizarteratu eta Laneratzeko Euskal Eredua erreferente bilakatu da, urte hauetan zehar desgaitasuna duten pertsonentzat lan-ingurune egoki bat eraikitzea lortu baitute. Ingurune honek lotura du Nazio Batuen Konbentzioak 27. artikuluan defendatzen duen ereduarekin, hau da, ingurune ireki, inklusibo eta bereizkeriarik gabekoa, non pertsonek askatasunez aukeratu ahalko duten burutu nahi duten lana. Azterlanean zehar ikusi dugunez, hurrengoak izan dira ereduaren arrakastaren faktore garrantzitsuenak:

- Desgaitasuna duten pertsonen gizarteratzea lortzeko, enplegua tresna eraginkorrenetako bat dela ulertzen dute.

- Entitateen antolaketan eta kudeaketan desgaitasuna duten pertsonen partaidetza bultzatzen dute, laguntza-behar handienak dituzten pertsonak lehenetsiz.

- Ingurune oso lehiakor eta profesionaletan jarduera mota desberdinak kudeatzen dituzte, gainera lan-merkatuko sektore gehienetan jarduten dute.

- Enplegagarritasun prozesuetan praktika berritzaileak erabiltzen dituzte, lan-aukera berriak sortuz.

- Eragile publiko, sozial eta ekonomiko desberdinekin egiten den lan koordinatua eta sarean funtsezkoa da.

- Finantzaketari dagokionez, entitateetako enplegagarritasun programek finantzaketa publiko egonkorra izan dute. Honetaz gain, entitateen kudeaketa profesionalizatuari esker, gizarte-ekimeneko enplegu-zentro bereziak jasangarriak eta finantzetan sendoak dira.

Faktore guzti hauei esker, Gizarteratu eta Laneratzeko Euskal Eredua oso egoera onean dago desgaitasuna duten pertsonen enpleguaren arloan. Hala ere, kolektiboaren lan egoera oraindik ez da gainontzeko populazioaren berdina eta desberdintasun handiak daude. Hori dela eta, etorkizunera begira hainbat erronka aurkezten dira, desgaitasuna duten pertsonentzat kalitate oneko enplegua sortzen jarraitzeko, eta beraien gizarteratzea osoa izateko. Beraz, gizarte-ekimeneko enplegu-zentro bereziek hurrengo erronkak dituzte:

- Erronka garrantzitsuena desgaitasuna duten pertsonentzat enplegu irisgarriago, irekiago eta inklusiboago bat sustatzen jarraitzea da, betiere, laguntza behar handienak dituzten pertsonak lehenetsiz.

- Formakuntzaren, enplegu lagunduaren eta lanbide-orientazioaren alorretan lanean jarraitu, hauen bitartez kolektiboak enplegua lortzea eta merkatu arruntera igarotzea hobetzeko asmoz.

- Desgaitasuna duten pertsonen kolektiboaren batez besteko soldata igotzea desgaitasuna ez duten pertsonen batez besteko soldatarekin berdindu arte, modu honetan, kolektiboaren autonomia ekonomikoa bermatuko litzateke. Honen harira, sindikatuekin negoziazio kolektiborako eredu egonkorra mantentzea da beste helburuetako bat.

- Praktika berritzaileak sortzea, lan-aukera berri eta zabalagoak lortzeko.

- Formakuntzaren alorrean, laguntza eta egokitzapenak garatzeko pausoak eman beharko dira, batez ere, derrigorrezko hezkuntzaren eta lanbide heziketaren artean dagoen etena murrizteko.

- Aurrera egitea formakuntzan eta ikasketan bizitza osoan zehar, hau da, etengabeko formakuntzan.

- Unibertsitatera sartzeko desgaitasuna duten pertsonen aukerak hobetzea.

- Enpresa pribatuari dagokionez, erronka garrantzitsuenetakoa enplegu-tasak hobetzea eta desgaitasuna duten pertsonak kontratatzeko derrigortasuna finkatzen duten arauak gehiago betetzea. Erabakigarria izango litzateke merkatu arrunteko enpresetara igarotzeko prozesuetan.

- Herri-administrazioaren alorrean, kolektiboa enplegu publikora sartzeko orduan aukeraberdintasuna lortzea, horretarako arlo publikoaren inplikazioa beharrezkoa izango da.

- Desgaitasuna duten pertsonak kontratatzeko derrigortasuna betetzen dela ziurtatzeko, Administrazioaren kontrol zorrotzagoak beharko dira, bai enpresa pribatuan, bai Herriadministrazioan ere.

- Bestalde, desgaitasuna duten pertsonen kolektiboak dituen zahartze edota narriadura goiztiarreko prozesuak kontuan hartuta, garrantzitsua da enpleguaren arloan zahartze aktiboa eta bizitza-kalitatea faboratzeko eredua finkatzea. Gizon eta emakumeen arteko berdintasunari dagokionez, desgaitasuna duten emakumeek diskriminazio bikoitza jasaten dute. Honi aurre egiteko, ezinbestekoa da emakumeak agerian jartzeko ekintzak eta sentsibilizazioa bultzatzea gizartean, emakumeek bizi duten egoera hau hobetzera lagunduko baitute. 
BENGOETXEA, A.; ETXEBARRIA, A.; MORANDEIRA, J. eta SOTO, A. (2019): Gizarteratu eta Laneratzeko Euskal Eredua / El modelo vasco de inserción sociolaboral, Donostia, Gizarte Ekonomia eta Zuzenbide Kooperatiboko Institutua.

DE FUENTES, C. (2016): “Sobre el concepto jurídico de persona con discapacidad y la noción de apoyos necesarios", Revista Española de Discapacidad, 4. bol., 2. zb., 81-99 or.

ESPAINIA (1985): “2273/1985 Errege Dekretua, abenduaren 4koa, 13/1982 Legeak, apirilaren 7koa, desgaitasuna duten pertsonen gizarte integraziokoa, 42. artikuluan definitzen dituen Enplegu-Zentro Berezien araudia onartzen duena", Boletín Oficial del Estado, abenduaren 9a, <https://www.boe.es/eli/es/ $\mathrm{rd} / 1985 / 12 / 04 / 2273$ '.

- (2000): “Kontseiluaren 2000/78/EE Zuzentaraua, 200oko azaroaren 27koa, enpleguan eta okupazioan tratu-berdintasunerako esparru orokorra ezartzeari buruzkoa", Boletín Oficial de las Comunidades Europeas, abenduaren 2a, 〈https://www.boe.es/buscar/doc. php?id=DOUE-L-2000-82357>.

- (2006): “39/2006 Legea, abenduaren 14koa, autonomia pertsonala sustatzeari eta mendetasun-egoeran dauden pertsonak zaintzeari buruzkoa", Boletín Oficial del Estado, abenduaren 15a, 〈https:// www.boe.es/eli/es/l/2006/12/14/39/con>.

- (2006): “469/2006 Errege Dekretua, apirilaren 21ekoa, lanbide-jarduerari laguntzeko unitateak arautzen dituena Enplegu-Zentro Berezien egokitze pertsonal eta sozialeko zerbitzuen esparruan", Boletín Oficial del Estado, apirilaren 22a, 〈https://www.boe.es/eli/es/ rd/2006/04/21/469>.
- (2007): “870/2007 Errege Dekretua, uztailaren 2koa, laguntzazko enplegu-programa arautzen duena, lan-merkatu arruntean desgaitasuna duten pertsonen enplegua sustatzeko", Boletín Oficial del Estado, uztailaren 14a, 〈https:// www.boe.es/eli/es/rd/2007/07/02/870>.

- (2011): “5/2011 Legea, martxoaren 29koa, Gizarte Ekonomiari buruzkoa”, Boletín Oficial del Estado, martxoaren 30a, <https://www.boe.es/ eli/es/l/2011/03/29/5).

- (2011):“26/2011 Legea, abuztuaren 1ekoa, araudia Desgaitasuna duten Pertsonei buruzko Eskubideen Nazioarteko Konbentziora egokitzekoa", Boletín Oficial del Estado, abuztuaren 3a, 〈https://www.boe.es/eli/ es/l/2011/08/01/26/con>.

- (2013): “1/2013 Legegintzako Errege Dekretua, azaroaren 29koa, desgaitasuna duten pertsonen eskubideei eta haien gizarteratzeari buruzko Lege Orokorraren Testu Bategina onartzen duena", Boletín Oficial del Estado, abenduaren 3a, 〈https://www.boe.es/eli/es/ $\mathrm{rdlg} / 2013 / 11 / 29 / 126 / 2011>$.

- (2015): “5/2015 Legegintzako Errege Dekretua, urriaren 3oekoa, Enplegatu Publikoaren Oinarrizko Estatutuaren Legearen testu bategina onartzen duena", Boletín Oficial del Estado, urriaren 31a, <https://www.boe.es/eli/es/ $\mathrm{rdlg} / 2015 / 10 / 30 / 5 /$ con>.

- (2017): “9/2017 Legea, azaroaren 8koa, Sektore Publikoko Kontratuena, Europako Parlamentuaren eta Kontseiluaren 2014ko otsailaren 26ko 2014/23/EB eta 2014/24/EB zuzentarauen transposizioa egiten duena Espainiako ordenamendu juridikora", Boletín Oficial del Estado, azaroaren 9a, 〈https://www.boe.es/ eli/es/l/2017/11/08/9/con>. 
GIZARTE EKONOMIAKO EUSKAL BEHATOKIA (2018): Informe anual de la situación de la economía social vasca, Gizarte Ekonomiako Euskal Behatokia.

MORATALLA, P. (2017): “El modelo vasco de inclusión sociolaboral de personas con discapacidad", Revista Vasca de Economía Social, 14. zb., 129-144 or.
NAZIO BATUEN ERAKUNDEA (2006): Desgaitasuna duten Pertsonen Eskubideei buruzko Nazioarteko Konbentzioa, New York, Nazio Batuen Erakundea, 〈http://www. convenciondiscapacidad.es〉.

TOBOSO, M. eta ARNAU, M.S. (2008): “La discapacidad dentro del enfoque de capacidades y funcionamientos de Amartya Sen", Araucaria, Revista Iberoamericana Filosofía, Política y Humanidades, 20. zb, 64-94. or. 